\title{
Informal Entrepreneurial Network Education as a Catalyst for Women's Enterprises Sustainability: Evidence From Nigeria
}

\author{
Adeola Adesola ESSIEN \\ Correspondence: Adeola Adesola ESSIEN, Department of Business Management, Atlantic International University \\ Hawali, USA.
}

Received: March 17, 2021

doi:10.11114/bms.v7i2.5191

\author{
Accepted: April 2, 2021 \\ Online Published: April 29, 2021 \\ URL: https://doi.org/10.11114/bms.v7i2.5191
}

\begin{abstract}
Extant studies in the literature have found that informal entrepreneurship education has concentrated largely on technical skills and has continually ignored the current needs of informal entrepreneurs at the stage of entry and development performance of most informal enterprises. In spite of Africa informal sector that accounted for $85.5 \%$ informal enterprises in size than other continents, yet, it is worrisome that the sub-Saharan Africa contribution of informal sector to gross domestic product (GDP) between 2000 and 2010 has dropped from $63.6 \%$ to $55 \%$, resulting to rising poverty rate, alarming youth unemployment rate, higher enterprises closure rate, and indeed, declining unstable enterprises. As such, this study empirically examines the impact of informal entrepreneurial network education on women's enterprises sustainability in Nigeria, using NECA Women entrepreneurs association. To achieve this specific objective, the study decomposed informal entrepreneurial network into three networks, the NECA Women entrepreneurs association, the Government agencies association, and the social media platform and the average value represent the informal entrepreneurial network education to regress on the dependent variable, the women enterprises sustainability. A total of 100 questionnaires were distributed and administered via the google survey from the six-geopolitical regions in Nigeria. The study employed statistical packages for social sciences (SPSS) to estimate the research questions and the impact of informal entrepreneurial network education on women enterprises sustainability, using descriptive statistics and OLS regression respectively. The descriptive results found that of the three informal entrepreneurial networks, NECA women association exhibited a strong interactive (3.28 of 5.00 Likert scale) entrepreneurial network education than use of government agencies and social media platform that exhibited weak interactive (1.8 and 1.94 of 5.00 Likert scale) enterperneurial network education among informal entrepreneurs in Nigeria. In addition, OLS regression result found that all three informal entrepreneurial networks education has a $38.9 \%$ impact on women's enterprises sustainability within the study periods of October and December, 2020 in Nigeria at 1\% level of significance. Based on the results, the study concluded that NECA women entrepreneurial interactive network outperformed both government agencies and social media interactive networks and thus, the study recommends that the NECA women entrepreneurs should consolidate more than the economic perspective by extending to the remaining triple bottom line factors such as environmental and social factors as to meet both current needs and future generation needs of the enterprises stakeholders in this study.
\end{abstract}

Keywords: Informal Entrepreneurship Education, Informal Entrepreneurial Network Education, Enterprises Sustainability

\section{Introduction}

Over the past four decades ago, the informal entrepreneurial activities in the informal sector were first recognized by the government in 1990s. Specifically, the debt crises, economic dwindling, and downsizing in the formal sector of the Latin America and Asiain the 1980s and 1990s led to formal jobs loss, high inflationary pressure and other negative macroeconomic indicators has paved way for renewed interest in informal sector development in both developed and developing countries (Gerxhani, 1999, Standing, 1999 cited in Williams, Martinez-Perez, and Kedir, 2016).

Although, prior to the 1990s, the governments perceived informal sector as unorganized, unrecorded and unregulated informal activities and thus resulted in tax evasion, government revenue lose, marginal and low productivity, wage exploitation and unable to create modern jobs to the increasing number of unemployed people (Williams, Martinez-Perez, and Kedir, 2016). Further, the literature in informal sector before 1990 also theorized informal sector from the dualistic, the structuralist, and the legalistic approaches. In spite of the increasing size and jobs creations by the 
informal sector in developing countries and in specific, about $80 \%$ informal enterprises created and over $90 \%$ jobs generated in Africa, yet, the government and the academics before 1990s saw informal sector as a traditional sector or undergrounded economy and thus, predicted that the informal sector activities will be absorbed into the formal sector and thus, disappeared (Lewis, 1954; ILO, 1972; Becker, 2004).

Contrary to the expectations of the government before 1990s and the early development economists literature like Lewis Dualistic theory (1954) and others, the informal sector has not only persisted but has exhibited a significant contributions in most developing countries and now reawakening the developed countries. In specific, the informal sector has outperformed the formal sector in terms of size, ownership, employment generations, poverty alienation, government and above all, accelerated economic growth and development achievements. For instance, in 2018, the informal sector size accounted for 2 billion working people, representing more than $6 \%$ of the World's employment population. Specifically, Africa informed sector created $85.8 \%$ employed while other continents like Asia, America and Europe accounted for $68.2 \%, 40 \%$, and $25.1 \%$ informal employment generations respectively. Indeed, Africa as a continent is the highest beneficiary of informal sector when compared with other continents in terms of jobs creation. Nonetheless, the nose-diving impact of informal sector on selected Africa macroeconomic indicators such as GDP, poverty alienation, gender participation and employment, became worrisome for policymakers, governments and academics. For example, between 2000s and 2010, the contribution of informal sector to GDP in sub-Saharan Africa dropped from $2 / 3$ of the GDP, representing $63.6 \%$ to $1 / 3$ of the GDP, representing $55 \%$. Indeed, the increasing size of informal sector has been inadvertently reduced the contribution of informal sector to the gross value added in Africa and even sub-Saharan Africa region (Lupi, 2018; EU, 2020: Verick, 2011). Similarly, the share of informal employment to total employment in sub-Saharan Africa has exhibited a continual rise from 70 percent in 1980s to 80 percent in 1990s but dropped from 78.3 percent in 2000s to 66.0 percent in 2010s.

Importantly, the self employment of about 80.4 percent outperformed the wage employment of less than 25 percent in the informal sector in sub-Saharan Africa. Although, the informal sector has not largely employed the labour force when compared with the formal sector but the remarkable self employed percentage implied that a greater number of African people had been alleviated from poverty through entrepreneurial activities in their different enterprises size in sub-Saharan Africa.

In addition, the gender participation in the informal sector is another significant macroeconomic indicator in existing literature. Comparing the sub-Saharan Africa with Middle East and North Africa (MENA) on gender participation in informal sector, it was found that the share of women in the informal sector is higher than men in the sub-Saharan Africa than MENA region. In specific, the women outnumbered the men in informal sector by 51.2percent in sub-Saharan Africa and also about 88.6 percent of women are self-employed in the informal sector than the men in sub-Saharan Africa. Although, the women self-employed and wage-employment in the informal sector are characterized with unproductive and unsustainable due to low educational status, lack of technology, home-based operations, little or no training or skills advancements, but to mention a few (Sparks and Barnett, 2010).

Table 1. Composition of Informal Sector Employment by Status and Gender Participation in Selected African Regions

\begin{tabular}{llc}
\hline Gender and African Regions & Employment Status in Informal Sector 2020 Self-Employed (\%) & Wage-Employment (\%) \\
\hline Women and Men & & \\
Africa (MENA) & 58.7 & 41.3 \\
Sub-Saharan Africa & 75.2 & 24.8 \\
Women & & \\
Africa (MENA) & 64.2 & 35.8 \\
Sub-Saharan Africa & 88.6 & 11.4 \\
Men & & \\
Africa (MENA) & 33.2 & 37.8 \\
Sub-Saharan Africa & 76.6 & 23.4 \\
\hline
\end{tabular}

Source: Researcher's compilation,

Following the low growth rates of women self-employment (women entrepreneurship) in MENA Africa and sub-Saharan Africa, this study is motivated to empirically investigate how informal entrepreneurial network education will promotes women enterprises growth and sustainability in Nigeria. Aside the rationale discussed, this paper follow specific sections: Section 1 presents the introduction, section 2 discusses the literature review while section 3 and 4 present data sources, methodology and analysis interpretation. Lastly, chapter 5 discusses the conclusion and recommendations of the study. 


\section{Literature Review}

\subsection{Conceptual Review}

\subsubsection{Concept of Informal Entrepreneurship}

The term informal entrepreneurship is one of the economic activities operated within the informal economy. According to International Labour Organization (ILO) (2012), informal entrepreneurship is defined as the process of establishing and managing an enterprise that engages in illicit economic activities operating fully or partially outside the purview of state regulatory arrangements, such as non-registration with regulatory authorities, non-payment of tax, or both. In sum, it comprises of all economic activities not fully covered by the formal arrangements, with the exception of criminal activities.

Importantly, informal entrepreneurs are the individuals by gender classification, that is, men and women who engaged in the pursuit of informal entrepreneurial activities but driven by different motives. Although, every informal entrepreneurs primarily operate for economic reasons such as profit, income, survival, growth, and most recent, sustainability, however, differ in the size and accomplishment of these economic reasons depending on individual entrepreneurs motives, varying from internal and external factors (Ladan, 2016). Besides, the individual economic reasons highlighted, the motives of informal entrepreneurship and informal entrepreneurs has transformed from individual economic reasons to developmental reasons such as poverty alleviation, employment generation, GDP growth rate, urbanization but to mention a few.

Informal entrepreneurship is categorized in two broad forms; Informal Entrepreneurship by Entry, and Informal Entrepreneurship by Performance.

\section{- Informal Entrepreneurship by Entry}

The informal entrepreneurship by entry is one of the categorization of informal entrepreneurship that focuses on the motives or the sociological intention of an entrepreneur to start-up an enterprise in a society or nation.

Though, a number of studies as classified different entry motives into two categories; the opportunity entrepreneurs and the necessity entrepreneurs (Ligthelm, 2013). According to Kelly, Bosma, and Amoros(2011) in the Global Entrepreneurship Monitor (GEM) identified that the opportunity entrepreneurs are those informal entrepreneurs who exploited a number of opportunities in the informal economies, ranging from modernization, structuralism, and institutional to maximize returns and grow enterprise sustainably. However, the opportunity entrepreneurs benefits by GEM prevails if the informal economies environments remain unchanged at the entry point and recently, the informal economies opportunities have continually changed, hence, rational and dynamic entrepreneurs must consider other external opportunities like the entrepreneurship networks to maximize returns and grow enterprise sustainably.

On the other hand, the Necessity entrepreneurs according to Kelly, Bosma, and Amoros (2011) in the Global Entrepreneurship Monitor (GEM) also identified that are those informal entrepreneurs that set-up enterprise to meet societal pressure, rather than scaring the informal economies to maximize returns and grow enterprise sustainably. Unfortunately, the necessity entrepreneurs exploit only the modernization that arises from the formal economy's inability to create sufficient jobs coupled with rising population growth due to rural-urban migration and thus, such static/traditional entrepreneurs lack the opportunity to exploit other external opportunities including structuralism, institutional and the recent, entrepreneurial networks advantages to maximize returns and sustain enterprises growth at the entry stage of informal entrepreneurship.

Second, Williams and Nadin (2010) also classified informal entrepreneurs at entry into two categories, the commercial and the social entrepreneurs. According, to Williams and Nadin (2010), commercial informal entrepreneurs are those that primarily operate wholly for profit reasons. While the social informal entrepreneurs are those who engaged in all sorts of unpaid informal entrepreneurial activities and social exchanges through self-employment to strengthen or achieve mutual relations, community exchange and above all, without profit-oriented, unlike the entry stage of informal entrepreneurship.

Third and lastly, another informal entrepreneurship at entry stage according to Webb, Tihanyi, Ireland, and Sirmon (2009), classified informal entrepreneurship at entry into three informal entrepreneurs-the income augmenting informal entrepreneurs, growth-oriented informal entrepreneurs, and the social-oriented informal entrepreneurs. The income-augmenting informal entrepreneurs are those informal entrepreneurs that constantly seek to change their current income while gaining in a work-paid employment. Also, the growth-oriented informal entrepreneurs are those entrepreneurs that are totally committed to the growth of the enterprise through a commercial-minded goal. Finally, the social-oriented informal entrepreneurs are those that desire a certain lifestyle without primarily income or profit driven motive at the entry stage of the informal entrepreneurship. 


\section{- Informal Entrepreneurship by Performance}

Under the informal entrepreneurship by performance, (Baumol, 1990 cited Ligthelm, 2013) classified informal entrepreneurship by performance into two distinguishing categories, productive and unproductive informal entrepreneurship. The productive informal entrepreneurship measures the outcomes of the informal entrepreneurship activities over a given period time, in terms of profit maximization, enterprise growth prospects, employment generation, poverty reduction, urbanization rate, and above all, economic growth and development in the enterprise as well as the community or society or nation (Ligthelm, 2013). On the other hand, unproductive informal entrepreneurship is the direct opposite of productive informal entrepreneurship that also measures the outcomes of the informal entrepreneurship. Basically, unproductive informal entrepreneurship connotes negative outcomes of the informal entrepreneurial activities, despite the increasing size of the informal entrepreneurs, such as low revenue, low profit, prevailing unemployment and poverty in the informal sector/economy. Importantly, the prevalence of unproductive informal entrepreneurship necessitated the yarning interest and need for integrated informal entrepreneurship education to change the unproductive informal entrepreneurship narrative to the productive informal entrepreneurship in most African countries, like Nigeria as case study in this study.

\subsubsection{Concept of Informal Entrepreneurship Education}

The term informal entrepreneurship education is the primitive and commonest type of entrepreneurship education widely practiced in developing countries like Africa and in Nigeria as case study. The informal entrepreneurship education is defined as informal entrepreneurship education that lacks structure and absence of curriculum through the transfer of practice-based knowledge only to prospective entrepreneurs at no specific time (Jackson, 2012.). Unlike formal and non-formal entrepreneurship education, entrepreneurial education, entrepreneurial skills are transferred through on the job training, mentoring, community-based training, and the commonest, the informal apprenticeship method (Ezenwakwelu, et al. 2019).

\section{- Informal On- The - Job Training}

The informal on the job training is the oldest from of informal entrepreneurship education as dated from the Medieval era. Informal on the job training is an approach for developing entrepreneurs' skills from experienced entrepreneurs through observation.

\section{- Coaching}

Another type of informal entrepreneurship education is coaching, which involves the process of transferring theory learning to practice. In otherwise, coaching is simply defined as a one-to-one training. Coaching is direct and fastest method of training technical knowledge and skills from experienced entrepreneurs to developing and prospects entrepreneurs. Though, coaching informal entrepreneurship education lacks limited scope of knowledge and skills because all entrepreneurial skills depend on solely on a single entrepreneur; unlike non-formal informal entrepreneurship education such as technical and vocational education and training (TVET).

\section{- Mentoring}

Mentoring is another form of informal entrepreneurship education that focuses more on altitudinal development rather than technical skills and knowledge transfers. Like coaching, mentoring is also one-to-one interaction method of informal entrepreneurship education.

\section{- Informal Apprenticeship Education}

Informal apprenticeship is one of oldest entrepreneurship education which is targeted at young people in African countries (ILO, 2012). The term informal apprenticeship education is defined as the mode of acquisition and transmission of skills and knowledge from a master to an apprentice for a long agreed period to gain proficiency. According to ILO (2009), informal apprenticeship simply refers to the primitive system by which a young apprentice acquires the skills for a trade or crafts in a micro or small enterprises, as well as learning and working side by side with an experienced practitioner. Specifically, informal apprenticeship learn not only technical skills but also the business culture and networking skills that makes the apprentice earner to start up the informal enterprise in the trained trade or crafts (ILO, 2009).

Though, informal apprenticeship education has largely increase youth employability, youth entrepreneurs enterprise productivity and thus foster local and economic development, yet, most informal apprentice enterprises lack management skills and enterprises sustainability which are the benefits of network entrepreneurship education in the recent periods.

\section{- Networks Entrepreneurship Education}

The network entrepreneurship education is the newest approach to informal entrepreneurship education that acquire and 
exploits external environment knowledge and skills, unlike other forms of informal entrepreneurship education whose knowledge and skills are limited to internal or single source not only to start-up informal enterprises but to manage entrepreneurs skills and sustain the informal enterprises (Adim, Adelaiye \& Ikechukwu, 2018).

The term networks entrepreneurship education was first suggested by Aldrich and Zimmer (1986) as an informal enterprise that are more successful than other informal enterprises in the entrepreneurship by entry and development performance, largely due to resource dependency theory (Jack, Moult, Anderson and Dodd, 2010). To put differently, networks entrepreneurship approach of informal entrepreneurship education placed emphasis on the gathering of tangible and intangible resources from external environments and thus, these resources are driven from the networks (Dodd et al. 2001 cited in Adim, Adelaiye \& Ikechukwu, 2018). Recently, the importance of networking in informal entrepreneurship education is to learn how relevant external resources are acquired and exploited for proficient enterprises management skills and sustainable enterprises economic over existing informal enterprises (Afazeli \& Ivanova, 2014).

In other words, networking entrepreneurial education is the process of acquiring social processes skills to exploit external resources including access to business opportunities, markets, ideas, information, finance, and others that propel the management skills of the informal enterprises as well as enterprises sustainability (Anderson, Dodd and Jack, 2012). In summary, the importance of networking entrepreneurship is basically to aid in resource and knowledge acquisition, innovation and growth of informal enterprises. Although, the types of network exploited by the entrepreneur are the main determinant of informal entrepreneur management skills and the informal enterprise sustainability in the literature, unlike the generic entrepreneurial networks which is not purposive and thus yields little impacts on enterprises performance.

\subsubsection{Entrepreneurial Informal Network Education}

The entrepreneurial informal network education is the foremost and the oldest from of entrepreneurial network education, which (Adrich \& Zimmer,1986 ited in Adim, Adelaiye \& Ikechukwu, 2018) defined as the personal relationships between an entrepreneur and his external actors (outside) who can be an individuals or an organizations, and primarily motivated for business purposes. Hence, these external relationships (contracts) are built by the entrepreneurs so as to obtain required resources and also serve as a vital source of competitive advantage at a considerable lower costs (Lawal, Adegbuyi, Iyiola, Ayoade, \& Taiwo, 2018).

Unlike the formal entrepreneurial network education which shows the relationship between managing directors within related industry and different industry and different industry as well as the relationship between different professionalisms such as trade association, chambers of commerce and others, informal entrepreneurial network education are more of interpersonal, and community based relationship between the informal entrepreneur and the external actors like friends, family, community associates, and community trade/informal enterprises association. Though, informal entrepreneurial network education and the social entrepreneurial network education are often used interchangeably but a distinction between informal entrepreneurial network education and social entrepreneurial network education from structural and process entrepreneurial networks perspectives was found (Lawal et al., 2018). Specifically, the informal entrepreneurial network is characterized as face-to-face network (relationship), high redundancy because the set of entrepreneurs almost show same resources and information and thus impact insignificantly to the informal enterprises growth and sustainability, low diversity, low and limited size and lastly, no or little technology communication aid between the ego(actor) and the external actors in informal entrepreneurial network education unlike social entrepreneurial network education that is diverse in culture, knowledge, information, resources, and communication medium such as Emails, Google, Whatsapp,twitter, and thus, characterized as low redundancies ties, high density, greater access to real-time knowledge, information and all-round needed resources for an entrepreneur relationship with external actors and importantly, supports the growth and sustainability of most informal enterprises (Jenssen, 2001; De Hoyos-Ruperto, Romaguera, Carlsson, \& Lyytinen, 2013).

\section{- Entrepreneurial Business Network Education}

Unlike entrepreneurial informal network education that exhibited relationship between an entrepreneur and unrelated external actors, the entrepreneurial business network education is basically a business platform relationship between an entrepreneur and other entrepreneurs to foster business interests in the midst of a competitive business environment. According to Soda, Usai \& Zaheer (2004), entrepreneurial business network education is a business social networking that educates an entrepreneur through communication with other entrepreneurs on how to access business opportunities, share information and resources as well as seek for informal enterprises partners prospects in achieving enterprises objectives collectively.

In the literature and practice, entrepreneurial business network education is obtained from two classifications, namely; inform entrepreneur associations and business firm aggregations. The informal enterprises associations are basically the 
relationship between an enterprise with other related informal enterprise in the same informal business while the informal enterprise aggregations exist when there is a relationship between a certain informal enterprise with other related informal enterprises to build a more dynamic, innovative and competitive informal enterprises against the formal enterprise in the market (Chung, Yang \& Huang, 2015).

Therefore, the entrepreneurial business network is a multifaceted informal enterprises network aimed to achieve quicker informal enterprises growth and sustainability than the entrepreneurial informal network due to diverse external resources from the main actors (direct actors) in terms of expertise, age of informal enterprises, and experiences in the market (Abbas, Raza, Nurunnabi, Minai \& Bano, 2019).

\section{- Entrepreneurial Social Network Education}

The entrepreneurial social network education is the recent and the widely means of networking an entrepreneur with diverse external resources due to the technology advancement in the business world. Unlike the entrepreneurial informal and business networks education, the entrepreneurial social network education is superior in terms of diverse contacts, non-redundancy, national and international connections, density and scope. In summary, the entrepreneurial social network education is extensive and combination of both entrepreneurial informal and business networks with dynamic changes in information technology (IT) to maximize the external actors resources through an entrepreneur relationship for enterprise growth, survival and sustainability (Sharada \& Lyer, 2015).

\subsubsection{Concept of Informal Enterprises Sustainability}

The term informal enterprises sustainability not new concept but a wider scope of informal enterprises that is driven by triple bottom line (TBL) such as economic, social and environment sustainability in an integrative model/approach. Unlike the informal enterprises that is only driven by economic sustainability at the expense of natural and social environment, the informal enterprises sustainability places emphasis on not only meeting the current needs but also meeting the future generation needs of the enterprises stakeholders (Soto-Acosta, Cismaru, Vatamanescu \& Ciochina, 2016).

In 1987, the term sustainability was reported in the Brundtland commission through the World Commission on Economic Development (WCED) and defined sustainable development as a meeting the needs of the present without compromising the ability of future generation to meet their own needs( Commission, 1987). Soto-Acosta et al. (2016) defined informal enterprise sustainability as a conscious and motivated action of an entrepreneur to continually solve not only economic problems but also social and environmental problems in achieving a long term enterprise objectives. In addition, Prabawani (2013) defined informal enterprises sustainability as a continuous ability of an entrepreneur to constantly resist external shocks as well as maximize internal enterprises growth in the long-run.

Importantly, the informal enterprises sustainability is aimed by entrepreneurs to balance both the internal interest and the external stakeholders' interest such as the governments, suppliers, trade associations, employees, communities, customers, and environment. In summary, the term of informal enterprise sustainability is measured from three constructs namely as the people, the planet and the profit and each represents the triple-bottom concept of social, environmental and economic.

\subsection{Theoretical Review}

Following the two main concepts discussed, informal entrepreneurial network education, and business management skills, the two underlying theories relevant for this study are resource-dependency theory and human capital theory.

\subsubsection{Resource Dependence Theory}

The resource dependence theory was developed in the book titled: "The External Control of Organizations" by Jeffrey Pfeifer and Gerald Salancik in 1978. According to Pfeifer and Salancik (1978), the Resource Dependency Theory (RDT) postulated that organizations actions and decisions depend solely on external resources from the environment (Nienhuser, 2008). Further, the RDT display the connection between environment, organization and organizational decisions or actions, and this connectivity is shown in figure1 as follows: 


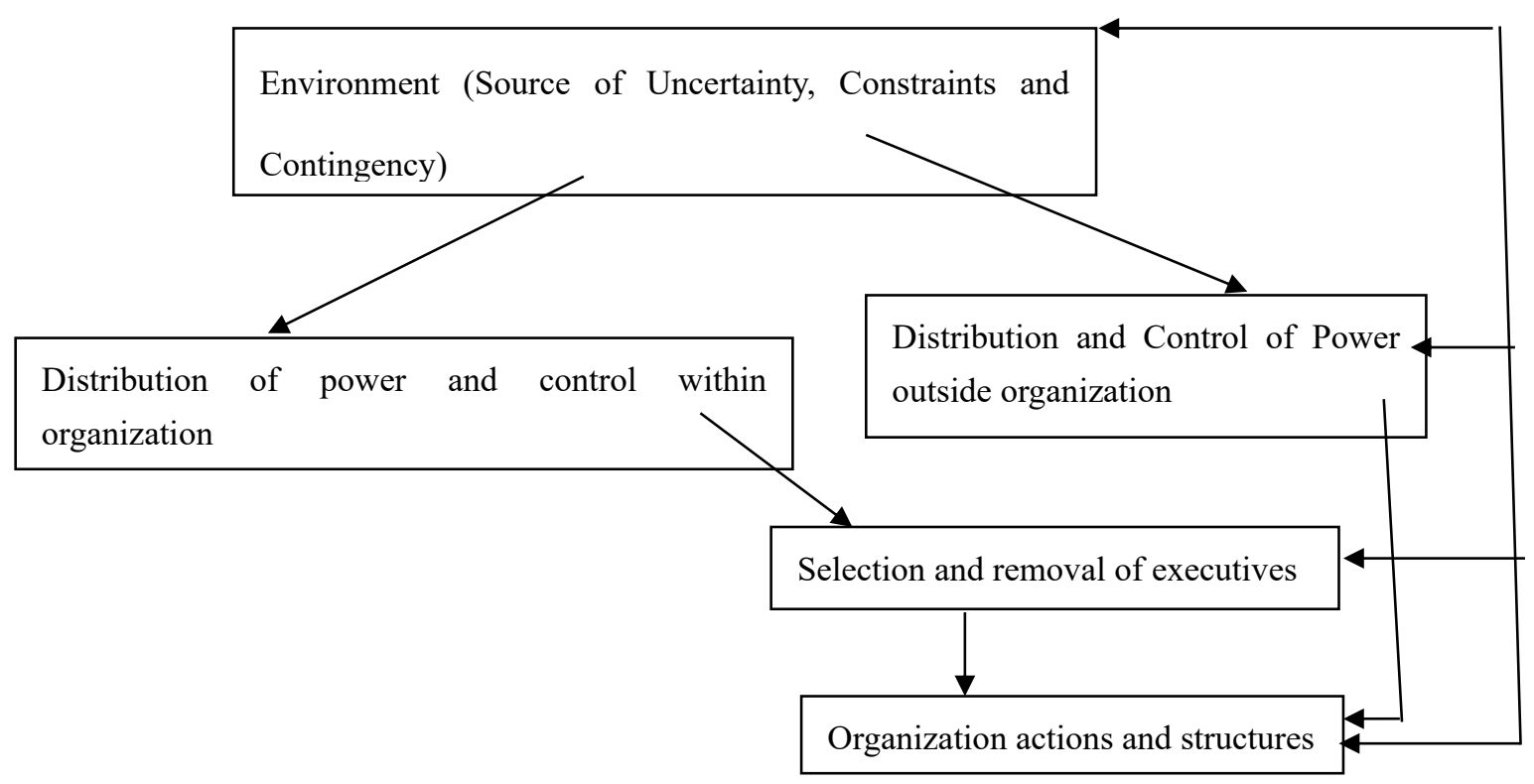

Figure 1. Connection between environment, organization and organizational decisions

Source: Pfeffer \& Salancik, 2003 cited in Nienhuser, 2008

The Figure 1 indicated the connection between environment, organization and organizational decisions or actions as displayed in five rectangular boxes. The first box shows the environment which is source of uncertainty, constant and contingency and includes suppliers, customers, governments, networks. The second box also shows the actions and decision with the organization while the third box displayed the actions and decision outside organization, that both influenced by the environment that is uncertain and uncontrollable. Lastly, the fourth and fifth rectangular boxes indicate the selection and removal of executives through the human/people skills and the fifth indicated the end result of the within and outside actions through the environment led to organization actions and structures implementation.

In summary, the resource dependency theory (RDT) has been widely implemented by most organizations as the main determinant of organization decisions/actions that depends solely on external resources but characterized as uncertainty and constraints by environmental resources.

Following the RDT assumptions that organizations actions/decision solely depend on external resources that are uncertain and constrained, as theorized in the past literature. Contrary, the future literature considers the need for organization to look inward and thus, consider the internal resources due to environmental constraints and uncertainty degree, hence, the resource-based view (RBV) theory was developed for the future literature.

The importance of the RDT and RBV theories cannot be overemphasized on organization decision/actions hence, the comparative literature concluded that the use of both RDT and RBV are essential to gain a competitive advantage for any rational organization.

In line to this study, the informal entrepreneurial education through entrepreneurial network should embrace integration of both external and internal resources to achieve women entrepreneurs' business management skills in the informal sector in Nigeria.

\subsubsection{Human Capital Theory}

The term human capital simply refers to any stock of knowledge or characteristics the worker or a self-employed has possessed or acquired through education, either formal or informal medium, motivated primarily to contribute positively to his or her productivity expressed quantitatively or qualitatively expressed in quantity or monetary.

The human capital theory is the extension of the Adam Smith's wage differentials between employments. Specifically, the early theories of human capital theory developed by Gary Backer and Theodore Schultz in 1960 emphasized on the role of investment in education to improve productivity. Although, each scholars acknowledged that there are different types of education,, ranged from formal, informal, on-the-job training and apprenticeships (Mincer, 1974 as cited in Sweetland, 1996). To this end, the early theories of human capital all emphasized on general education acquisition as an impetus for employees' or self-employed productivity and earnings from others.

Unlike the early human capital theories led by the pioneer, Gary Backer Theodore Schultz, and Jacob Mincer in 1960s 
that emphasizes on general knowledge acquisitions from the different type of education but little or no consideration for the importance of specific-knowledge and "residual" stock of knowledge as revealed by Gibbons and Waldman (2004) and Solow growth model.

Importantly, the modern human capital theory is notion as the task-specific human capital, unlike the general-human capital approach that has been practiced in most formal and informal education. In specific, the modern human capital coined as task-specific human capital was developed in 2004 by Robert Gibbons, an economist at MIT and Micheal Waldman, an economist at Cornell University. Further, the "residual" human capital developed by Solow also acknowledged the importance of "unobserved" stock of knowledge that is needed for a sustainable productivity of employee and self employed in an economy (Holden \& Biddle, 2017).

In summary, the human capital theory from the modern literature acknowledged the importance of task-specific knowledge acquisition as well as the development of "unobserved" skills/knowledge to meet current entrepreneurial needs and also to sustain the enterprises in the long run.

Following the extensive review of the past and modern literature on human capital theory, the comparison opined that productivity of an individual, or enterprise or industry largely depends on the combination of general-skills and specific skills to meet the immediate and future needs of any economic units. Importantly, the comparison of human capital theory past and modern in relation to this study recognizes the acquisition and combination of informal education and entrepreneurial network education, which is a specific-skill to achieve women business management skills in Nigeria.

\subsubsection{Stakeholder Theory}

The Stakeholder theory is one of the management theories that played emphasis on the interconnections between a business entity and all those who have a stake in business operations and survival of the business entity (Bhasin, 2020). Historically, the taught for the stakeholder theory in management was traced to the definition of Parker Follet in 1912. Notably, the R. Edward Freeman book titled :'Strategic Management: A Stakeholder Approach in 1984 originally detailed and publicized the stakeholder theory as an interconnected relationships between a business and its customers, suppliers, investors, committee, and others who have a stake in the entity.' Importantly, the theorized that firm should identify with all stakeholders and not only the internal \& external owners, often known as shareholders.

Aside the underlying theory of stakeholder, the past literature extensively discussed the different stakeholder approaches. Three stakeholder approaches include descriptive, instrumental and normative as distinguished by Donaldson \& Preston (1995). First, the descriptive stakeholder is concern on how the firm or entity operations affect the stakeholders of the firm, hence, it justify those stakeholders that are paramount for the firm profitability or economic reasons not only at short-run but in the long run (Bhasin, 2020). Second, the normative stakeholder is a continuation of descriptive stakeholder, which emphasizes on the type of stakeholders to be acknowledged as stakeholders, either individual or groups, as an external resources to achieve organizational objectives. Lastly, the third stakeholder approach is instrumental developed by Donaldson \& Preston (1995) to identify the links between management of stakeholders and the attainment of corporate objectives, which is attainable empirical data analysis.

In spite of the past literature on the role of stakeholder theory in achieving a long run organizations objective through the identification of a number of stakeholder's agents, but the modern literature on stakeholder theory now has placed more emphasis on the method or mode of interconnections of the business entity with the identified stakeholders (Bhasin, 2020). Importantly, the modern literature on stakeholder theory has gained more prominent to networking theory neither through physical or virtual (electronic medium) connectivity of all stakeholders for long-run achievement of the corporate entity.

Having compared the past and modern literature on stakeholder theory, it is evident that the two literatures are relevant to achieve a competitive ahead at a minimal cost in the long run. In line with this study, every successful entrepreneurs will adopt the past stakeholder theory to identify who constitute its network contacts through the descriptive stakeholder theory that has analyse the external resources carefully as well as the use of modern stakeholder theory to identify the appropriate links to manage the identified networks contacts with the enterprise.

\section{Sample, Data Source and Methodology}

In this study, the NECAs Network of Entrepreneurial Women Network constitutes the study population located in five Chapters of Nigeria, including Lagos State, Abuja State, Rivers State, Ogun State and Kwara State. Of the total NECA membership of 962 members as of October 2020, the study randomly selected 100 active members across the five Chapters as the sample. This study employed primary data to elicit relevant information through the Google Survey form from the respondents between October and December, 2020. Table 2 shows the distribution of the questionnaire for each Chapters of NECA as follows: 
Table 2. Questionnaire Distributions of NECAs in each Chapters

\begin{tabular}{|c|c|c|c|c|c|c|}
\hline \multirow{2}{*}{$\begin{array}{l}\text { Network } \\
\text { Levels }\end{array}$} & \multicolumn{5}{|c|}{ NECAs Chapters Distribution } & \multirow[t]{2}{*}{ Total } \\
\hline & $\begin{array}{l}\text { Lagos } \\
\text { Chapter }\end{array}$ & Abuja Chapter & $\begin{array}{l}\text { Rivers } \\
\text { Chapter }\end{array}$ & $\begin{array}{l}\text { Ogun } \\
\text { Chapter }\end{array}$ & $\begin{array}{l}\text { Kwara } \\
\text { Chapter }\end{array}$ & \\
\hline $\begin{array}{l}\text { Business } \\
\text { Network }\end{array}$ & 72 & 07 & 07 & 07 & 07 & 100 \\
\hline Total & 72 & 07 & 07 & 07 & 07 & 100 \\
\hline
\end{tabular}

Source: Researcher's computation, 2020 from NECA Data

Besides the sample and data source, the study employed descriptive and inferential statistics to achieve objective for this study. In specific, the questionnaire is broadly divided into three sections. Section one consists of part A, B, and C, representing the entrepreneur profile which is a mixed of qualitative and quantitative respondents' responses while sections 2 and 3 represented entrepreneurial informal network education and women's enterprises sustainability, which are in quantitative data of a 5 Likert-scales responses from the respondents were used to test the research hypothesis and answered the research objective in this study.

Specifically, the hypothesis is tested using descriptive statistics and inferential statistics. The descriptive statistics employed mean, standard deviation and skewness to describe the respondents' responses rate on the entrepreneurial network whether the entrepreneurial network is interactive or not with the degree of interactiveness as well as distribution patterns of the respondents responses, whether it is normally distributed or not. When distribution are normally distributed it implies that the respondents responses are one tailed either to the right tail (positive responses) or left tail (negative responses) all the respondents' responses are same or balance but when the responses are asymmetrical, it implies the responses. On the other hand, the simple regression analysis employed is to examine the impact of informal entrepreneurial networks education on women enterprises sustainability in Nigeria. Unlike, earlier studies ofAbbas, Raza, Nurunnabi, Minai \& Bano (2019), Sharada and Iyer (2015), Ogunnaike and Kehinde (2013), Mamabolo, Kerrin, \& Kele (2017), and Soto-Acosta, Cismaru, Vatamanescu \& Ciochina (2016) that investigated the entrepreneurial business networks using different methodology but this study extended their scope of entrepreneurial business networks from the different social media channels to include NECA specific associations, representing chamber of commerce or trade associations membership, and government agenecies interactive network, hence, this study exploit three different entrepreneurial interactive networks. Therefore, the functional relationship between informal entrepreneurial network education on women enterprises sustainability as adapted from the works of Abbas, Raza, Nurunnabi, Minai \& Bano (2019), Sharada and Iyer (2015), Ogunnaike and Kehinde (2013), Mamabolo, Kerrin, \& Kele (2017), and Sato-Acosta, Cismaru, Vatamanescu \& Ciochina (2016) is expressed in the functional model as expressed:

$$
\text { IES =f ( EBNE)--------------------------------------------(i) }
$$

Where

IES = Informal Enterprises Sustainability

EBNE $=$ Entrepreneurial Business Network Education 


\section{Results and Discussion}

\subsection{Descriptive Results}

4.1.1 Data Analysis of Entrepreneurial Business Network Education from NECA Associations Questions

Table 3. EBNE Descriptive Statistics Result

\begin{tabular}{|c|c|c|c|c|c|c|}
\hline Descriptive Statistics & $\mathrm{N}$ & Minimum & Maximum & Mean & Std. Deviation & Skewness \\
\hline $\begin{array}{l}\text { I interact with other entrepreneurs on how to } \\
\text { access financial credit from banks. }\end{array}$ & 84 & 1 & 5 & 2.87 & 1.34 & 0.18 \\
\hline $\begin{array}{l}\text { Iinteract with other entrepreneurs on how to } \\
\text { discover new market and products }\end{array}$ & 85 & 1 & 5 & 3.47 & 1.24 & -0.43 \\
\hline $\begin{array}{l}\text { I interact with other entrepreneurs on how to } \\
\text { enhance entrepreneurs skills through training and } \\
\text { workshop. }\end{array}$ & 85 & 1 & 5 & 3.99 & 1.19 & -1.19 \\
\hline $\begin{array}{l}\text { I interact with other entrepreneurs to source for } \\
\text { financing facilities from private and government } \\
\text { financial institutions. }\end{array}$ & 84 & 1 & 5 & 2.89 & 1.23 & 0.21 \\
\hline $\begin{array}{l}\text { Iinteract with other entrepreneurs to educate on } \\
\text { price setting of products }\end{array}$ & 85 & 1 & 5 & 2.98 & 1.29 & -0.09 \\
\hline $\begin{array}{l}\text { I interact with other entrepreneurs to share new } \\
\text { information and knowledge about the current } \\
\text { business environment. }\end{array}$ & 85 & 1 & 5 & 3.88 & 1.11 & -1.06 \\
\hline $\begin{array}{l}\text { I interact with other entrepreneurs to scan the } \\
\text { environment to identify new business } \\
\text { opportunities like new products, new supplies } \\
\text { and others. }\end{array}$ & 85 & 1 & 5 & 3.28 & 1.28 & -0.20 \\
\hline $\begin{array}{l}\text { Iinteract with other entrepreneurs on how to } \\
\text { formalize business operations }\end{array}$ & 84 & 1 & 5 & 3.49 & 1.22 & -0.49 \\
\hline $\begin{array}{l}\text { Iinteract with other entrepreneurs on how to } \\
\text { access market opportunities }\end{array}$ & 84 & 1 & 5 & 3.58 & 1.18 & -0.52 \\
\hline $\begin{array}{l}\text { Iinteract with other entrepreneurs for packaging } \\
\text { of product }\end{array}$ & 83 & 1 & 5 & 3.13 & 1.31 & -0.22 \\
\hline $\begin{array}{llll}\text { Iinteract with other entrepreneurs for } \\
\text { standardization }\end{array}$ & 82 & 1 & 5 & 3.22 & 1.14 & -0.14 \\
\hline Iinteract with other entrepreneurs for branding & 82 & 1 & 5 & 3.32 & 1.18 & -0.32 \\
\hline $\begin{array}{l}\text { I interact with other entrepreneurs to acquire } \\
\text { diverse knowledge about the formal sector } \\
\text { market. }\end{array}$ & 82 & 1 & 5 & 3.52 & 1.09 & -0.53 \\
\hline $\begin{array}{l}\text { Iinteract with other entrepreneurs to invest in } \\
\text { business opportunities in the formal sector market }\end{array}$ & 81 & 1 & 5 & 2.78 & 1.11 & 0.34 \\
\hline $\begin{array}{l}\text { I interact with other entrepreneurs to develop a } \\
\text { partnership to meet the customers' need } \\
\text { regionally and nationally }\end{array}$ & 82 & 1 & 5 & 2.84 & 1.23 & 0.15 \\
\hline 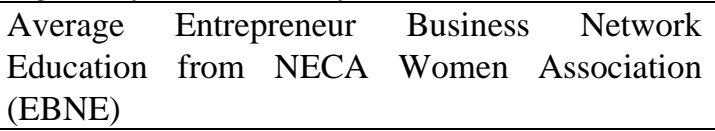 & & & & 3.28 & 1.21 & -0.29 \\
\hline
\end{tabular}

Source: Researcher's computation from SPSS 24, 2020

Table 3 shows the sample size, minimum, maximum, mean, standard deviation, and skewness for fifteen (15) research questions to describe the Entrepreneurial Business Network Education (EBNE) of NECA women entrepreneurs in this study. In specific, table 3 contains seven columns that provides the descriptive statistics results for Entrepreneurial Business Network Education (EBNE) in this study. First, column one contained15 research questions to answer the research question of this study. Second, column two displayed the sample size which indicated the number of respondents that responded to each research questions and more importantly, the minimum and maximum respondents are 81 and 85 entrepreneurs respectively. The column two results indicated that not all the expected respondents answer all the research questions, rather, their variations by respondents for each research question in this study. Third, columns 3 and 4 show the minimum and maximum Likert scale values of 1 and 5 respectively. The columns 3 and 4 results 
indicated that responses to the research questions exhibited a constant wide variation from NECA women entrepreneurs on Entrepreneurial Business Network Education (EBNE) in this study. Fourth, column 5 exhibited the mean values for each research question and aggregate research questions in this study. Importantly, the entire mean values for each research question were above 2.50 out of 5.00 , hence, the mean values for each research are high and frequently interactive but none is above 4.00 in approximation in this study. Further, the mean value for the aggregate research questions was 3.28 out of 5.00, implying that the entrepreneurial business network education responses from the average NECA women entrepreneurs are frequently interactive in this study. Fifth, column 6 presented the standard deviation for each research question and aggregate research questions in study. The standard deviation values for each research question are far from zero and the lowest and highest deviation around the mean are 1.09 and 1.34 respectively in this study. This suggested that responses to each question are largely different from each NECA women entrepreneurs and thus implied that the interaction of entrepreneurial business network education among NECA women entrepreneurs are largely different from each other in this study. Lastly, the column six exhibited the degree of skewness for each research question in this study. Importantly, all the research questions are both positively and negatively skewed and thus implied the NECA women entrepreneurs' responses were in both positive and negative directions and all the 15 research questions are not normally distributed in this study.

In summary, the descriptive results of the fifteen (15) research questions on entrepreneurial business network education concluded that there is a frequent interaction with entrepreneurs on entrepreneurial business network education among the selected NECA women entrepreneurs in Nigeria within the study periods between October and December 2020.

4.1.2 Data Analysis of Entrepreneurial Business Network Education from Nigeria Government Agencies Questions

Table 4. EBNENGA Descriptive Statistics Result

\begin{tabular}{|c|c|c|c|c|c|c|}
\hline Descriptive Statistics & $\mathrm{N}$ & Minimum & Maximum & Mean & $\begin{array}{l}\text { Std. } \\
\text { Deviation }\end{array}$ & Skewness \\
\hline $\begin{array}{l}\text { My enterprise through the entrepreneurial business } \\
\text { networks interacts with Nigerian government } \\
\text { enterprises agencies to provide credit finance }\end{array}$ & 81 & 1 & 3 & 1.85 & 0.79 & 0.27 \\
\hline $\begin{array}{l}\text { My enterprise through the entrepreneurial business } \\
\text { networks interacts with Nigerian government } \\
\text { enterprises agencies to provide training }\end{array}$ & 81 & 1 & 4 & 1.70 & 0.83 & 1.01 \\
\hline $\begin{array}{l}\text { My enterprise through the entrepreneurial business } \\
\text { networks interacts with Nigerian government } \\
\text { enterprises agencies to provide seminars \& } \\
\text { workshops }\end{array}$ & 69 & 1 & 5 & 1.86 & 1.13 & 1.37 \\
\hline $\begin{array}{l}\text { My enterprise through the entrepreneurial business } \\
\text { networks interacts with Nigerian government } \\
\text { enterprises agencies to provide business clinics }\end{array}$ & 62 & 1 & 5 & 1.60 & 0.90 & 1.61 \\
\hline $\begin{array}{l}\text { My enterprise through the entrepreneurial business } \\
\text { networks interacts with Nigerian government } \\
\text { enterprises agencies to provide exhibitions }\end{array}$ & 79 & 1 & 5 & 2.05 & 1.14 & 0.91 \\
\hline $\begin{array}{l}\text { My enterprise through the entrepreneurial business } \\
\text { networks interacts with Nigerian government } \\
\text { enterprises agencies to provide trade missions }\end{array}$ & 81 & 1 & 3 & 1.85 & 0.79 & 0.27 \\
\hline $\begin{array}{l}\text { My enterprise through the entrepreneurial business } \\
\text { networks interacts with Nigerian government } \\
\text { enterprises agencies to provide information } \\
\text { dissemination }\end{array}$ & 81 & 1 & 4 & 1.70 & 0.83 & 1.01 \\
\hline $\begin{array}{l}\text { Average Entrepreneur Business Network Education } \\
\text { from Nigeria Government Agencies (EBNENGA) }\end{array}$ & & 1 & 4 & 1.8 & & \\
\hline
\end{tabular}

from Nigeria Government Agencies (EBNENGA)

Source: Researcher's computation from SPSS 24, 2020

Table 4 shows the sample size, minimum, maximum, mean, standard deviation, and skewness for seven (7) research questions to describe the Entrepreneurial Business Network Education from Nigerian Government agencies in this study. In specific, table 4 contains seven columns that provides the descriptive statistics results for Entrepreneurial Business Network Education from Nigerian Government agencies (EBNENGA) in this study. First, column one consist of seven research questions that describes Entrepreneurial Business Network Education from Nigerian Government agencies. Second, column two showed the sample size that responded to each research question, however, it revealed unbalanced 
respondents for each research question and the minimum and maximum respondents for the seven questions are 62 and 81 respectively. This suggested that not all the selected NECA women entrepreneurs benefitted the Entrepreneurial Business Network Education from Nigerian Government agencies. Third, column three and four showed the minimum and maximum Likert score values. Like table 5.1, the minimum Likert scores remained same for the seven questions while the maximum values for the seven questions are different ranging from 3 to 5 . This suggested that each question has different range value, unlike table 5.1 in this study. Fourth, column 5 exhibited the mean values for each question that describes Entrepreneurial Business Network Education from Nigerian Government agencies. Specifically, all the mean values for each question are not above the average Likert scores, except 1.85 and 1.85 for questions 1 and 6 respectively. Also, column 5 showed the mean values for the aggregate research questions of Entrepreneurial Business Network Education from Nigerian Government agencies was 1.8 and thus, implied that average NECA women entrepreneurs did not frequently interact with the Nigeria government agencies on entrepreneurial business network education in this study. Fifth, column 6 showed the standard deviation for each research question as well as the aggregate research questions. In specific, each research question responses from NECA women entrepreneurs are different and deviate around the mean in this study. Lastly, the column 7 found that the degree of skewness for each question is asymmetrical and positively skewed. This result confirmed that the NECA women entrepreneurs responses on the interaction with the Nigeria government agencies on entrepreneurial business network education are all on positive directions and in same vein like table 3, all the research questions are not normally distributed in this study. In summary, the descriptive results for the seven (7) research questions on the interaction with the Nigeria government agencies on entrepreneurial business network education concluded that there is no frequent interaction among the selected NECA women entrepreneurs in Nigeria within the study periods between October and December 2020.

\subsubsection{Data Analysis of Entrepreneurial Business Network Education from Social Media Platforms Questions}

Table 5. EBNESMP Descriptive Statistics Result

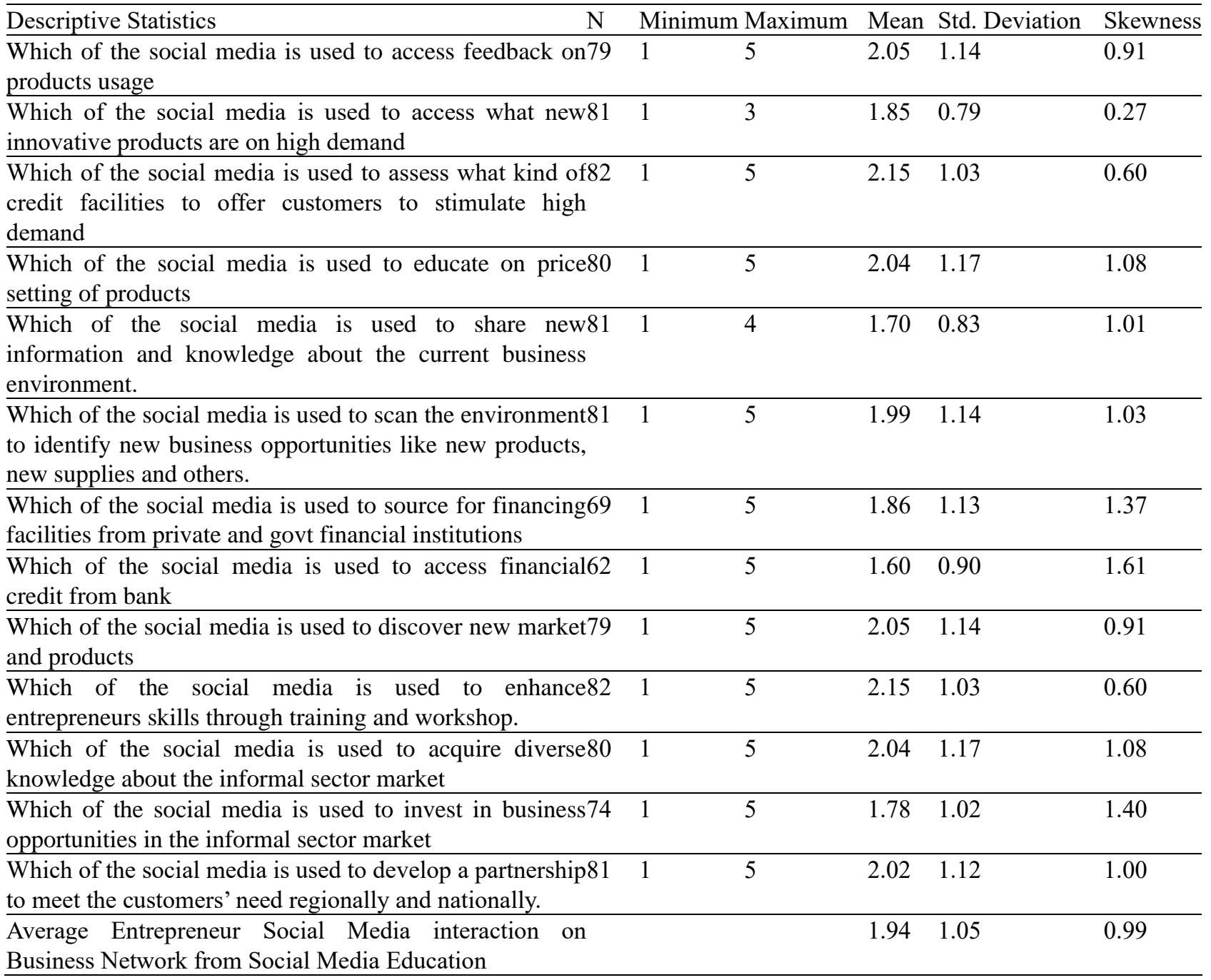


Table 5 showed the research questions, sample size, minimum, maximum, mean, standard deviation, and skewness for thirteen (13) research questions to describe the Entrepreneurial Business Network Education through social media platforms used by NECA women entrepreneurs in this study. In specific, table 5 displayed seven columns that present the descriptive statistics results for Entrepreneurial Business Network Education (EBNE) through social media platforms in this study. First, column one contained13 research questions to answer the research question of this study. Second, column two showed the sample size of the NECA women entrepreneurs that responded to each research question in this study. Like tables 3 and 4, the numbers of respondents were not equal in each question responded. Specifically, the lowest and highest respondents in the thirteen questions are 62 and 82 respondents in this study. This suggested that not all expected respondents used any of the social media to interact the Entrepreneurial Business Network Education in this study. Third, columns 3 and 4 showed the minimum and maximum Likert scale values which ranged from 1 to 5, except questions 2 and 5 that ranged from 1 to 3 and 1 to 4 respectively. Like table 3, it indicated equal range values in the thirteen questions, except questions 2 and 5 that exhibited unequal range scores in this study. This indicated that NECA women entrepreneurs responses on social media interactions usage have a wide deviations, implying that social media interactions usage are largely different from each other in this study. Fourth, column 5 showed the mean values for each research question under social media usage interactions on Entrepreneurial Business Network Education in this study. Importantly, all the mean values except 1.85 are not above average Likert scores of 2.50 in the thirteen questions of this study. This suggested that the average NECA women entrepreneurs used not more than two social media platforms to interact the Entrepreneurial Business Network Education in this study. Fifth, column 6 showed the standard deviation values for each research question in this study. In specific, the standard deviations for each research question is far from zero, hence, the NECA women entrepreneurs responses are not same and largely different for each research question in this study. Lastly, column 6 exhibited the degree of skewness for each research question in this study. Importantly, the skewness values for each question were all positively skewed and hence, none of the research question responses from NECA women entrepreneurs on social media sage are normally distributed in this study. In summary, the descriptive results for the thirteen (13) research questions on the degree of social media interaction with entrepreneurial business network education concluded that there is a low degree of social media interaction on entrepreneurial business network education from the selected NECA women entrepreneurs in Nigeria within the study periods between October and December 2020.

\subsubsection{Data Analysis of Enterprises Sustainability}

Table 6. ES Descriptive Statistics Results

\begin{tabular}{|c|c|c|c|c|c|}
\hline Descriptive Statistics & Minimum & Maximum & Mean & Std. Deviation & Skewness \\
\hline $\begin{array}{l}\text { Our enterprise products yields attainable profit, } 81 \\
\text { turnover \& market size }\end{array}$ & 2 & 5 & 4.23 & 0.71 & -0.81 \\
\hline $\begin{array}{l}\text { Our enterprise operates within entrepreneurial } 84 \\
\text { networks for achievable attainable profit, cost } \\
\text { minimum, turnover and market size }\end{array}$ & 2 & 5 & 4.19 & 0.69 & -0.72 \\
\hline $\begin{array}{l}\text { Our enterprise contribute to the welfare of the } 82 \\
\text { workforce }\end{array}$ & 3 & 5 & 4.50 & 0.57 & -0.61 \\
\hline $\begin{array}{l}\text { Our enterprise contribute to the community } 84 \\
\text { development }\end{array}$ & 2 & 5 & 4.50 & 0.57 & -0.61 \\
\hline $\begin{array}{l}\text { Our formal enterprises activities create no harm } 84 \\
\text { to the consumer, and community }\end{array}$ & 2 & 5 & 4.38 & 0.62 & -0.78 \\
\hline Average Enterprises Sustainability (AES) & & & 3.72 & 0.82 & -0.44 \\
\hline
\end{tabular}

Source: Researcher's computation from SPSS 24, 2020

Table 6 showed the research questions, sample size, minimum, maximum, mean, standard deviation, and skewness for six (6) research questions that describe the enterprises sustainability of the NECA women entrepreneurs in Nigeria in this study. In specific, table 6 contains for six columns that presents the descriptive statistics results enterprises sustainability of the NECA women entrepreneurs in this study. First, column one consist of six research questions relating to enterprises sustainability from three theoretical underpinning in this study. Second, column two displayed the number of respondents that administered each research question in this study. Unlike table 5, all the respondents for each research question are less than the expected 85 respondents and the lowest and highest actual respondents are 81 and 84 respectively for each research question in this study. Third, columns 3 and 4 showed the minimum and maximum Likert scale of 1 to 5 , although, some research questions only ranged 2 to 5 . This indicated unequal range values for each research question in this study. Fourth, column 5 exhibited the mean value for each research question and found that all the mean values for enterprises sustainability from NECA women entrepreneurs responses were all above 2.50 and indicated a high mean values of enterprises sustainability for the selected NECA women entrepreneurs 
in this study. Fifth, column 6 showed the standard deviation for each research question and found that all standard deviations are not equal to zero but exhibited a low deviations from zero in this study. This indicated that NECA women entrepreneurs responses on enterprises sustainability are relatively different but not wide variations for each research question. Finally, column 7 exhibited the degree of skewness for each research question and found that all skewness values were all negatively skewed and thus implied that NECA women responses on enterprises sustainability are on negative directions and not normally distributed in this study. In summary, the descriptive results for the six (6) research questions on the enterprises sustainability inferred that the selected NECA women entrepreneurs in Nigeria strongly agree to enterprises sustainability within the study periods between October and December 2020.

\subsection{Hypothesis Testing Result}

\subsubsection{Hypothesis Result}

Ho: There is no relationship between informal entrepreneurial networks education on women enterprises sustainability in Nigeria

Table 7. Summary of Estimated Regression for informal entrepreneurial business networks education on women enterprises sustainability. Dependent Variable: Average Enterprises Sustainability (AES) Regression Results

\begin{tabular}{lcc}
\hline Dependent Variables & AES & \multicolumn{1}{c}{ OLS Model } \\
\hline Average Entrepreneurial Business Networks Education (AEBNE) & $0.389^{* * *}(3.83)$ \\
\hline Constant & 0.50 & $2.73^{* * *}(9.04)$ \\
\hline R Squared & 0.25 & \\
\hline Durbin-Watson (DW) & 1.54 \\
\hline Number of Observations (N) & 46 \\
\hline F-Statistic & $14.67^{* *[0.000]}$ \\
\hline
\end{tabular}

Source: Researcher's computation from SPSS 24, 2020

Note: $* * *$ significant at $1 \%$ level, $* *$ significant at $5 \%$ level, and $*$ significant at $10 \%$ level;t-statistics are in brackets while p-values are in parentheses; AES, and AEBNE are variables represented as average enterprises sustainability,and average entrepreneurial business network education in this study. OLS Model represented the functional relationship between average enterprises sustainability and average entrepreneurial business network education and denoted as $\mathrm{AES}=\mathrm{f}(\mathrm{AEBNE})$.

Hypothesis result as shown in table 7 achieved the objective of this study. Specifically, table 7 showed the summary of estimated regression of the effects of informal entrepreneurial networks education on women business management skills in Nigeria. First, the OLS model presented the regression result of the impact of entrepreneurial business network education on average enterprises sustainability within the study period October and December, 2020. Specifically, the entrepreneurial business network education coefficient of 0.389 indicated a positive and significant impact of average entrepreneurial business network education on average enterprises sustainability within the study October and December, 2020. Also, the constant coefficient value of 2.73 found that other factors not included in this model have a positive and significant impact on average enterprises sustainability in this study. Further, the diagnostic regression results of multiple correlation (R) and the R-squared values of $50 \%$ and $25 \%$ indicated that a strong relationship existed between average entrepreneurial business network education and average enterprises sustainability as well as a change in average enterprises sustainability is accounted by 25 percent change in average entrepreneurial business network education while the 75 percent changes in the dependent variable is accounted by other residual factors not included in this model. In addition, the Durbin-Waston value of 1.54 indicated the presence of a negative autocorrelation, which is a contrary to the OLS assumption in this study. Finally, the F-statistic value of 14.67 at p-value [0.000] implied that the overall model is statistically significant at $1 \%$ level of significance, hence, it is concluded that there is a statistical relationship between average entrepreneurial business network education and average enterprises sustainability within the study periods, October and December, 2020.

\section{Conclusion and Recommendations}

This study empirically investigated the impact of informal entrepreneurial network education on women's enterprises sustainability in Nigeria, using NECA as a case study. Based on the descriptive statistics and OLS regression approaches, the outcome of this study concludes that the informal entrepreneurial network education has a positive and reliable impact on the NECA women enterprises sustainability within the study periods of October and December, 2020 in Nigeria. To this end, this study recommends that the NECA entrepreneurs should not only consider entrepreneurial network education from the economic perspective only but emphasis should be placed on other triple bottom line 
factors such as environmental and social factors tomeets both current needs and future generation needs of the enterprises stakeholdersin this study.

\section{References}

Abbas, J., Raza, S., Nurunnabi, M., Minai, M. S., \& Bano, S. (2019). The impact of entrepreneurial business networks on firm's performance through a mediating role of dynamic capabilities. Sustainability, MDPI. https://doi.org/10.3390/su11113006

Adim, V., Adelaiye, M. O., \& Ikechukwu, A. E. (2018). Entrepreneurial networking and women entrepreneurs contribution to employment creation in Rivers State, Nigeria. International Journal of Business, Economics and Management. Retrieved from www. researchgate.net/publications/327670876

Afazeli, A., \& Ivanora, V. (2014). The role of entrepreneurship networking on Internalization of a micro-sized born global Swedish fashion company. A B.Sc. Thesis at Hogskolan Darlan.

Aldrich, H. E., \& Zimmer, C. (1986). Entrepreneurship Through Social networks. California Management Review, 33, $1-2$.

Anderson, A. R., Dodd, S., \& Jack, S. (2012) entrepreneurship as connecting some implications for theorising and practice. Management decision, 5095, 958-971. https://doi.org/10.1108/00251741211227708

Baumol, W. J. (1990). Entreprneruship: Productive, Unproductive, destructive. Journal of Political Economy, 98(5), 893-921. https://doi.org/10.1086/261712

Becker, K. F. (2004). The informal economy Swedish International Development Agency Stockholm.

Bhasin, H. (2020). What is the stakeholder theory strategy? Marketing, 91.

Botha, M., Nieman, G., \& Vuuren, J. V. (2006). Enhancing female entrepreneurship by enabling access to skills. The International Entrepreneurship and Management Journal, 2(4), 479-493. https://doi.org/10.1007/s11365-006-0011-2

Chung, H. F. L., Yang, Z., \& Huang, P. H. (2015): How does organizational learning matter in strategic business performance? The contingency role of guanxi networking Journal of Business Research, 68, 1216-1224. https://doi.org/10.1016/j.jbusres.2014.11.016

De-Hoyos-Ruperto, M., Romaguera, J. M., Carlsson, B., \& Lyytinen, K. (2013). Networking: A critical success factor for entrepreneurship. Academy journal of Management, 13(2), 55-72.

Donaldson, T., \& Preston, L. E. (1995) The Stakeholder theory of the corporation: concepts, evidence, and implications. The academy of management review, 20(1), 65-91. https://doi.org/10.5465/amr.1995.9503271992

Enikanselu, S. A. (2011). Management: Theory and Philosophy. Sabo-Yaba: Enykon Consult.

Ezenwakwelu, C. A., Egbosionu, N. A., \& Okwo, H. U. (2019). Apprenticeship Training Effects on Entrepreneurship Development in Developing Economies. Academy of Entrepreneurship Journal, 25(1), 1-21.

Gerxhani, K. (1999). Informal Sector in developed and less developed countries: A Literature Survey. Tinbergen Institute Discussion Papers No.99-083/2

Gibbons, R., \& Waldman, M. (2004). Task-specific human capital. American Economic review, 94(2), 203-207. https://doi.org/10.1257/0002828041301579

Hisrich, R. D., \& Peters, M. P. (2005). Entrepreneurship National Economic Trends, 1-2.

Holden, L., \& Biddle, J. (2017). The introduction of human capital theory into education policy in the United States. History of Political Economy, 49(4), 537-574. https://doi.org/10.1215/00182702-4296305

International Labour Organization (ILO). (2012). Women and men in the informal economy: A statistical picture. Geneva: International Labour Office and Women in Informal Employment: Globalizing and Organizing.

Jack, S., Moult, S., Anderson, A. R., \& Dodd, S. (2010). An entrepreneurial network evolving: Patterns of change. The International Small Business Journal, 28(4), 315-337. https://doi.org/10.1177/0266242610363525

Jackson, T. (2012). Cross-cultural management and the informal economy in sub-Saharan Africa: implications for organization, employment and skills development. The International Journal of Human Resource Management, 23(14), 2901-2916.

Jenssen, J. I. (2001). Social networks, resources and entrepreneurship. The International journal of Entreprneurship and innovation, 103-110. https://doi.org/10.5367/000000001101298846 
Katz, R. L. (1995). Skills of an effective administrator. Harvard Business Review, 23(1), 33-42.

Kelly, D. J., Bosma, N., \& Amoros, J. E. (2011). Entrepreneurship Monitor 2010 Global Report, 1-85.

Ladan, U. (2016). Evaluating informal entrepreneurship in Nigeria: A study of Zamfara State. A PhD Thesis, University of Sheffield, 1-277.

Lawal, F. A., Adeguyi, O. A., Iyiola, O. O, Ayoade, O. E., \& Taiwo, A. A. (2018). Nexus between informal networks and risk-taking: Implications for improving the performance of small and medium enterprises (SMEs) in Nigeria academy of Strategic Management Journal, 17(2), 1-13.

Lewis, W. A (1954). Economic development with unlimited supplies of labour. Manchester School of Economic and Social Studies, 23(2). https://doi.org/10.1111/j.1467-9957.1954.tb00021.x

Ligthelem, A. A.(2013). Confusion about entrepreneurship? Formal versus informal small business. Southern African Business Review, 17(3), 1-19.

Love, C., \& Baronet, J. (2012). Toward a new entrepreneurial skills and competencies framework: A qualitative and quantitative study. International journal of Entrepreneurship and Small Business, 17(4), 455-477. https://doi.org/10.1504/IJESB.2012.050164

Lupi, A. (2018) Main Sectoral approaches of policies designed to tackle the informal economy. Retrieved from https://europa.eu/capacity4dev/msf-mst

Mamabolo, A., Kerrin, M., \& Kele, T. (2017). Entrepreneurship management skills requirements in an emerging economy: A South African outlook. The Southern African Journal of Entrepreneurship and small business management, 9(1), 1-10. https://doi.org/10.4102/sajesbm.v9i1.111

Nienhuser, W. (2008). Resource dependency theory: How well does it explain behaviour of organizations? Management Revenue, Rainer Hampp Verlag, Mering, $19(1 / 2), \quad 9-32, \quad$ ISSN $\quad 1861-9916$. https://doi.org/10.5771/0935-9915-2008-1-2-9

Ogumnaike, O., \& Kehinde, O. J. (2013). Social networking and business performance. The case of selected entrepreneurs in Ota, Nigeria. J. Business Administration Management Science Research, 2(5), 116-122.

Pfeffer, J., \& Salancik, G. R. (1978). The external control of organization: A Resource Dependence perspective New York.

Sharada, B., \& Iyer, P. P. (2015). Social networks for entrepreneurship: How do entrepreneurs benefit from their informal networks? Entrepreneurial Ecosystem. https://doi.org/10.1007/978-81-322-2086-2 7

Soda, G., Usai, A., \& Zaheer, A. (2004). Network Memory: The influence of past and current networks on performance. The Academy of Management Journal, 47(6), 893-906. https://doi.org/10.2307/20159629

Soto-Acosta, P., Cismaru, D., Vatamanescu, E. M., \& Ciochina, R. S. (2016). Sustainable Entrepreneurship in SMEs: A business performance perspective. Economic and Business Aspects of sustainability, 8(4), 342-354. https://doi.org/10.3390/su8040342

Sparks, D. L., \& Barnett, S. T. (2010) The informal sector in sub-Saharan Africa: Out of the shadows to foster sustainable employment and equity. The International Business and Economics Research journal (IBER), 9(5), 1-12. https://doi.org/10.19030/iber.v9i5.563

Standing, G. (1999). Global labour Flexibility: Seeking distribute justice. New York; St. Martins Press. https://doi.org/10.1007/978-1-349-27576-2

Sweetland, S. R. (1996) Human Capital theory: Foundations of a field of Inquiry. Review of Educational Research, 66(3), 341-359. https://doi.org/10.3102/00346543066003341

Webb, J. W., Tihanyi, L., Ireland, R. D., \& Sirmon, D. G. (2009). You say illegal; I say legitimate: Entrepreneurship in the Informal economy. Academic of Management Review, 34(3), $492-510$. https://doi.org/10.5465/amr.2009.40632826

Williams, C. C., \& Nadin, S. (2010). Entrepreneurship and the informal economy: An overview. Journal of Developmental Entrepreneurship, 15(4), 361-378. https://doi.org/10.1142/S1084946710001683

\section{Copyrights}

Copyright for this article is retained by the author(s), with first publication rights granted to the journal.

This is an open-access article distributed under the terms and conditions of the Creative Commons Attribution license which permits unrestricted use, distribution, and reproduction in any medium, provided the original work is properly cited. 